DOI

\title{
КОГНІТИВНІ ПОРУШЕННЯ ПРИ ЕКСПЕРИМЕНТАЛЬНІЙ ЧЕРЕПНО-МОЗКОВІЙ ТРАВМІ
}

\author{
๑О. О. Стародубська, С. В. Зябліцев, М. І. Піщуліна
}

Національний медичний університет імені О.О. Богомольця, м. Київ, Україна

РЕЗЮМЕ. Травматичне ушкодження головного мозку залишається актуальною проблемою у сфері медичних та соціально-економічних питань. Важливим аспектом черепно-мозкової травми (ЧМТ) $є$ когнітивні порушення, що призводять до розвитку ускладнень та інвалідизації постраждалих.

Мета дослідження - визначити особливості когнітивних порушень при експериментальній ЧМТ.

Матеріал та методи. Моделювання ЧМТ проведено на 65 білих безпородних щурах-самцях за методикою В. М. Єльського, С. В. Зябліцева (2005). Для вивчення когнітивних розладів використовували тести «відкрите поле», «норковий рефлекс» та використовували експеримент із восьмирукавним лабіринтом.

Результати. ЧМТ призводила до суттєвого пригнічення когнітивних функцій у тварин безпосередньо після ЧМТ, а впродовж місяця відбувалося ії відновлення. Проте, як свідчать результати дослідження, показники орієнтовно-рухової активності, норкового рефлексу та експерименту «восьмирукавний лабіринт» наприкінці місяця після травматичного ушкодження не досягли рівнів показників контрольної групи тварин.

Висновки. Отримані дані свідчать про розвиток вірогідних порушень когнітивних функцій не тільки у найближчі після травми дні, а й у віддаленому періоді чМТ. Відсутність повного відновлення когнітивних функцій свідчила про доцільність використання таргетних фармакологічних засобів відповідної спрямованості в посттравматичному періоді.

КЛючовІ СлОВА: черепно-мозкова травма; когнітивні порушення.

Вступ. Травматичне ушкодження головного мозку залишається актуальною проблемою як у сфері медичних, так і соціально-економічних $[2,7]$ питань. Завдяки широкому колу досліджень патогенезу черепно-мозкової травми (ЧМТ), удосконаленню методів діагностики, визначенню особливостей клінічного перебігу, дослідженню нових фармакологічних засобів лікування при своєчасному наданні спеціалізованої медичної допомоги рівень летальності знижується [2]. Але виникають проблеми розвитку ускладнень та інвалідизації постраждалих від ЧМТ [4]. Когнітивні порушення можуть виникати вже у гострому періоді травматичного ушкодження мозку, але, як свідчать численні дані досліджень, зростання кількості випадків сприятливого перебігу ЧМТ супроводжується психоневрологічними порушеннями у віддаленому періоді $[6,8,9]$. Особливостями травми мозку $\epsilon$ подовження строків вторинного ушкодження внаслідок аутонейросенсибілізації та розвитку аутоагресії, імунодефіциту, ліквородинамічних та мікроциркуляторних порушень [3]. Когнітивні розлади у віддаленому періоді ЧМТ проявляються як порушенням пам'яті, так і уповільненням процесів обробки інформації, зниженням концентрації та уваги [6].

Отже, залишаються актуальними як пошуки ефективних медикаментозних засобів лікування ЧМТ з метою запобігання когнітивним порушенням і проведення ефективної реабілітації пацієнтів з травмою мозку, так і достовірних критеріїв ефективності фармакологічних засобів $[5,7,9]$.
Мета дослідження - визначити особливості когнітивних порушень при експериментальній ЧMT.

Матеріал і методи дослідження. Моделювання ЧМТ проведено на 65 білих безпородних щурах-самцях віком від шести до семи місяців, вагою 175-215 г, при вільному доступі до ̈̈жі та води. Експерименти проводили з дотриманням Гельсінської декларації, прийнятої Генеральною асамблеєю Всесвітньої медичної асоціації (2008р.), загальних норм та принципів Європейської конвенції про захист хребетних тварин, що використовуються для дослідницьких й інших наукових цілей, Першого Національного Конгресу з біоетики та законодавства України. Відтворення ЧМТ проводили вільнопадаючим вантажем на фіксовану голову тварини за методикою В. М. Єльського, С.В. Зябліцева (2005) [1]. Дослідна група включала 50 тварин з ЧМТ, контрольна група - 15 хибнотравмованих тварин. Для вивчення когнітивних розладів використовували тести «відкрите поле» (кількість пересічених квадратів та оглянутих отворів) та «норковий рефлекс» (НР), що дозволяли оцінити орієнтувальну та рухову активність (ОРА), дослідну діяльність, навички навчання, емоційність та тривожність тварин. Також використовували експеримент із восьмирукавним лабіринтом (ВЛ), у якому вивчалася робоча (тимчасова) і референтна («семантична», «довготривала») пам'ять. Вимірювали кількість заходів в рукави з годівницями без повторів, тобто чи пам'ятає щур, що заходив у цей рукав, чи ні, а також навик, що виробляється з часом, обстежувати рукави за виробленою методикою 
Огляди літератури, оригінальні дослідження, погляд на проблему

запам'ятовування, тобто навчання. Статистичні розрахунки здійснили в середовищі прикладних програм Statistica 10 (StatSoft, Inc, USA).

Результати й обговорення. При аналізі ОРА, НР та ВЛ у тварин контрольної групи протягом 30 діб вірогідних відмінностей між показниками пересічених квадратів, кількості оглянутих отворів, часу переходу до темної камери та кількості вдалих заходів до рукавів виявлено не було ( $>>0,05)$. Тобто, сам процес вимірювання не впливав на когнітивні функції тварин контрольної групи.

Після ЧМТ у тварин спостерігали значні зміни всіх показників, порівняно з тваринами контрольної групи (табл. 1).

Так, на 1 добу після моделювання ЧМТ у тварин спостерігалося зменшення кількості пересічених квадратів у тесті "відкритого поля" 3 $(14,46 \pm 1,67)$ до $(2,81 \pm 0,97)$ (на $80,6 \% ; p<0,05)$; кількість оглянутих отворів зменшилася 3 $(11,46 \pm 1,53)$ до $(1,31 \pm 0,06$ (на $88,6 \% ; p<0,05)$. Таке різке зменшення кількості оглянутих отворів вказувало на повну відсутність мотивації, цікавості та когнітивних здібностей після відтворення ЧМТ.

Спостерігалося різке збільшення латентного часу переходу щура до темної камери, НР склав $(201,2 \pm 15,3)$ с, проти $(54,2 \pm 14,7)$ с у тварин контрольної групи, тобто збільшився на 271,2 \% $(p<0,05)$. Кількість вдалих заходів до рукавів із годівницями також різко зменшилася - $3(7,3 \pm 0,58)$ до $(0,8 \pm 0,06)$ (на $89,1 \% ; p<0,05)$. Такі низькі показники вказували на виражені мнестичні порушення і випадковість заходу тварин до рукавів.

На 3 добу експерименту спостерігалися незначні позитивні зміни. Кількість пересічених квадратів збільшилася на 10,1 \% і склала $(4,26 \pm 0,76)$, кількість оглянутих отворів зросла на 9,9\%, а тривалість латентного часу НР хоч і зменшилася на $32,8 \%$, проте перевищувала показники контрольної групи на 238,4 \% $(p<0,05)$ що вказувало на наявність дезорієнтованості тварин та неспроможність знайти нірку (когнітивні порушення). Кількість вдалих заходів до рукавів із годівницями також мала тенденцію до збільшення, проте невірогідну ( $p>0,05)$, і залишалася на рівні випадковості: $(1,7 \pm 0,09)$ проти $(7,3 \pm 0,58)$ у тварин контрольної групи, що свідчило про явні когнітивні порушення у тварин з ЧМТ.

На 7 добу після ЧМТ у групі порівняння показники ОРА продовжували збільшуватись: порівняно 31 добою кількість пересічених квадратів зросла на $16,1 \%$, а кількість оглянутих тваринами отворів збільшилася на 20,4 \% (р>0,05). НР склав $(137,3 \pm 14,2$ с, тобто час переходу щура до темної камери знизився на $85,1 \%(p<0,05)$, порівняно 3 попереднім строком спостереження, а відносно 1 доби після травми - на 117,9 \% (р>0,05), що вказувало на початок відновлення орієнтованості тварин та когнітивних функцій. Кількість вдалих заходів до рукавів із годівницями на 7 добу також мала вірогідну тенденцію до збільшення - на $39,8 \%$ вище за 1 добу $(p<0,05)$.

На 14 добу після ЧМТ у групі порівняння показники ОРА щурів у відкритому полі продовжували змінюватися. Так, кількість пересічених квадратів склала $44,4 \%(p<0,05)$ від показників контрольної групи тварин, кількість оглянутих отворів збільшилася на 25,9 \% порівняно з 1 добою після травми, але залишалася на $62,7 \%$ $(p<0,05)$ меншою по відношенню до тварин контрольної групи. НР склав $(107,4 \pm 15,8)$ с, проти $(54,2 \pm 14,7)$ с у тварин контрольної групи, тобто

Таблиця 1. Показники орієнтувально-рухової активності, норкового рефлексу та експерименту «восьмирукавний

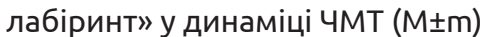

\begin{tabular}{|c|c|c|c|c|c|}
\hline Показник & 1 доба & 3 доба & 7 доба & 14 доба & 30 доба \\
\hline \multicolumn{6}{|c|}{ Кількість пересічених квадратів, одиниць } \\
\hline Контроль & \multicolumn{5}{|c|}{$14,46 \pm 1,67$} \\
\hline Дослідна група & $2,81 \pm 0,97^{*}$ & $4,26 \pm 0,76^{*}$ & $5,13 \pm 1,46^{*}$ & $6,42 \pm 1,21 *$ & $6,97 \pm 1,73^{*}$ \\
\hline \multicolumn{6}{|c|}{ Кількість оглянутих отворів, одиниць } \\
\hline Контроль & \multicolumn{5}{|c|}{$11,46 \pm 1,53$} \\
\hline Дослідна група & $1,31 \pm 0,06^{*}$ & $2,44 \pm 0,97^{*}$ & $3,65 \pm 0,87^{*}$ & $4,28 \pm 1,08^{*}$ & $5,87 \pm 0,92 *$ \\
\hline \multicolumn{6}{|c|}{ Норковий рефлекс, секунд } \\
\hline Контроль & \multicolumn{5}{|c|}{$54,2 \pm 14,7$} \\
\hline Дослідна група & $201,2 \pm 15,3^{*}$ & $183,4 \pm 12,3 *$ & $137,3 \pm 14,2^{*}$ & $107,4 \pm 15,8 *$ & $95,5 \pm 16,3$ \\
\hline \multicolumn{6}{|c|}{ Кількість вдалих заходів до рукавів, одиниць } \\
\hline Контроль & \multicolumn{5}{|c|}{$7,3 \pm 0,58$} \\
\hline Дослідна група & $0,8 \pm 0,06 *$ & $1,7 \pm 0,09 *$ & $3,7 \pm 0,91 *$ & $4,1 \pm 0,86^{*}$ & $4,9 \pm 0,63^{*}$ \\
\hline
\end{tabular}

Примітка. ${ }^{-}$р $<0,05$ при порівнянні середніх величин з контрольною групою. 
Огляди літератури, оригінальні дослідження, погляд на проблему

спостерігалося зменшення латентного часу переходу до темної камери на 173 \% $(p<0,05)$, порівняно $з 1$ добою після травми. Кількість вдалих заходів до рукавів із годівницями на 14 добу також мала вірогідну тенденцію до збільшення - на 45,3 \% вище за 1 добу $(p<0,05)$. Отже, отримані дані свідчили про повільне, але позитивне відновлення когнітивних функцій у тварин з ЧМТ.

На 30 добу після ЧМТ у дослідній групі кількість пересічених квадратів статистично значуще не збільшилася, порівняно з попереднім строком спостереження, і склала 48,2 \% від показників контрольної групи тварин. Кількість оглянутих тваринами отворів збільшилася на $13,9 \%(p<0,05)$, порівняно з даними на 14 добу. HР склав $(95,5 \pm 16,3)$ с, що було на $76,2 \%(p<0,05)$ більше по відношенню до тварин контрольної групи. Кількість вдалих заходів до рукавів із го- дівницями на 30 добу також мала вірогідну тенденцію до збільшення - на 56,2 \% $(p<0,05)$ вище, ніж за 1 добу.

Таким чином, ЧМТ призводила до суттєвого пригнічення когнітивних функцій у тварин безпосередньо після ЧМТ, тоді як впродовж місяця відбувалося ії відновлення. Проте, як свідчили результати дослідження, показники ОРА, НР, ВЛ наприкінці місяця після травматичного ушкодження не досягали рівнів показників контрольної групи тварин.

Висновки. Отримані дані свідчать про розвиток порушень когнітивних функцій не тільки у гострому, але й у віддаленому періоді ЧМТ. Відсутність довільного відновлення когнітивних функцій свідчить щодо необхідності використання таргетних фармакологічних засобів відповідної спрямованості в посттравматичному періоді.

\section{ЛІТЕРАТУРА}

1. Ельский В. Н. Моделирование черепно-мозговой травмы / В. Н. Ельский, С. В. Зяблицев. - Донецк : Новый мир, 2008. - 140 с.

2. Захаров В. В. Когнитивные нарушения у больных с черепно-мозговой травмой / В. В. Захаров, Е. А. Дроздова // Неврология, нейропсихиатрия, психосоматика. - 2013. - № 4. - С. 88-93.

3. Зябліцев С. В. Механізми запальних та аутоімунних реакцій при черепно-мозковій травмі / С. В. Зябліцев, Я. С. Юзьків // Патологія. - 2016. - № 1 (36). - С. 9-53.

4. Когнітивні розлади у віддаленому періоді черепно-мозкової травми як причина обмеження життєдіяльності потерпілих / В.М.Школьник, Г. Д. Фесенко, В. А. Голик [та ін.] // Український нейрохірургічний журнал. - 2015. - № 2. - С. 5-10.

5. Cognitive-communication rehabilitation for combat-related mild traumatic brain injury [Електронний ресурс] // J. Rehabil. Res. Dev. - 2012. - Vol. 49 (7).
- P.xi-xxxii. - Режим доступу: http://www.rehab.research. va.gov/jour/2012/497/pagexi.html

6. Draper K. Cognitive functioning ten years following traumatic brain injury and rehabilitation / K. Draper, J. Ponsford // Neuropsychology. - 2008. Vol. 22 (5). - P. 618-625.

7. Helmick K. Cognitive rehabilitation for military personnel with mild traumatic brain injury and chronic postconcussional disorder: Results of April 2009 consensus conference / K. Helmick // Neuro Rehabilitation. - 2010. - Vol. 26 (3). - P. 239-255.

8. Rabinowitz A. R. Cognitive sequelae of traumatic brain injury / A. R. Rabinowitz, H. S. Levin // Psychiatr. Clin. North Am. - 2014. - Vol. 37 (1). - P. 1-11.

9. Tsaousides T. Cognitive rehabilitation following traumatic brain injury: assessment to treatment / T. Tsaousides, W. A. Gordon // Mt. Sinai J. Med. - 2009. Vol. 76 (2). - P. 73-81.

\section{REFERENCES}

1. Elskiy, V.N., \& Ziablitsev, S.V. (2008). Modelirovanie cherepno-mozgovoi travmy [Design of brain injury]. Donetsk: Novyi mir. [in Russian].

2. Zakharov, V.V., Drozdova, E.A. (2013). Kognitivnye narusheniya u bolnykh s cherepno-mozgovoy travmoy [Cognitive disorders in patients with cranio-cerebral injury]. Nevrologiya, neyropsihiatriya, psikhosomatika Neurology, Neuropsychiatry, Psychosmatics, 4, 88-93 [in Russian].

3. Zyablitsev, S.V., \& Yuzkiv, Ya.S. (2016). Mekhanizmy zapalnykh ta autoimunnykh reaktsiy pry cherepno-mozkoviy travmi [Mechanisms of inflammatory and autoimmune reactions when cranio-cerebral injury]. Patolohiia - Pathology, 1 (36), 49-53. [in Ukrainian].

4. Shkolnyk, V.M., Fesenko, H.D., Holyk, V.A.,
Pohoryelova, S.A., Pashkovskyi, V.I., \& Huk A.P (2015). Kohnityvni rozlady u viddalenomu periodi cherepnomozkovoi travmy yak prychyna obmezhennia zhyttiediialnosti poterpilykh [Cognitive disorders in remote period of cranio-cerebral injury as a reason of limited activity of victims]. Ukrainskyi neuirokhirurhichnyi zhurnal Ukrainian Neurosurgical Journal, 2, 5-10. [in Ukrainian].

5. Cognitive-communication rehabilitation for combat-related mild traumatic brain injury (2012). J. Rehabil. Res. Dev., 49 (7), xi-xxxii. http://www.rehab. research.va.gov/jour/2012/497/pagexi.html

6. Draper K., \& Ponsford, J. (2008). Cognitive functioning ten years following traumatic brain injury and rehabilitation. Neuropsychology, 22 (5), 618-25. doi: 10.1037/0894-4105.22.5.618. 
Огляди літератури, оригінальні дослідження, погляд на проблему

7. Helmick, K. (2010). Cognitive rehabilitation for military personnel with mild traumatic brain injury and chronic post-concussional disorder: Results of April 2009 consensus conference. Neurorehabilitation, 26 (3), 239255. doi: 10.3233/NRE-2010-0560.

8. Rabinowitz, A.R., \& Levin, H.S. (2014). Cognitive

sequelae of traumatic brain injury. Psychiatr. Clin. North Am., 37 (1), 1-11. doi: 10.1016/j.psc.2013.11.004.

9. Tsaousides, T. \& Gordon, W.A. (2009). Cognitive rehabilitation following traumatic brain injury: assessment to treatment. Mt. Sinai J. Med., 76 (2),173-181. doi: 10.1002/msj.20099.

\section{КОГНИТИВНЫЕ НАРУШЕНИЯ ПРИ ЭКСПЕРИМЕНТАЛЬНОЙ ЧЕРЕПНО-МОЗГОВОЙ TPABME}

ОА. О. Стародубская, С. В. Зяблицев, М. И. Пищулина

Национальный медицинский университет имени А. А. Богомольца, г. Киев, Украина

РЕзЮМЕ. Травматическое повреждение головного мозга остается актуальной проблемой, как в сфере медицинских вопросов, так и - социально-экономических. Важным аспектом черепно-мозговой травмы (ЧМТ) являются когнитивные нарушения, которые приводят к развитию осложнений и инвалидизации пострадавших.

Цель исследования - определить особенности когнитивных нарушений при экспериментальной ЧМТ.

Материалы и методы. Моделирование ЧМТ проведено на 65 белых беспородных крысах-самцах по методике В. Н. Ельского, С. В. Зяблицева (2005). Для изучения когнитивных расстройств использовали тесты «открытое поле», «норковый рефлекс» и эксперимент с восьмирукавным лабиринтом.

Результаты. ЧМТ приводила к существенному угнетению когнитивных функций у животных непосредственно после ЧМТ, с постепенным их восстановлением в течение месяца. Однако, как показали результаты исследования, показатели ориентировочно-двигательной активности, норкового рефлекса и эксперимента «восьмирукавный лабиринт» через месяц после травматического повреждения не достигли уровней показателей контрольной группы животных.

Выводы.Полученные данные свидетельствовали о развитии значительныхнарушений когнитивных функций не только в ближайшие сроки после травмы, но и в отдаленном периоде. Отсутствие полного возобновления когнитивных функций свидетельствовало о целесообразности использования таргетных фармакологических средств соответствующей направленности в посттравматическом периоде.

КЛЮЧЕВЫЕ СЛОВА: черепно-мозговая травма; когнитивные нарушения.

\section{COGNITIVE DYSFUNCTION AT EXPERIMENTAL TRAUMATIC BRAIN INJURY ๑O. O. Starodubska, S. V. Ziablitsev, M. I. Pischulina \\ O. Bohomolets National Medical University, Kyiv, Ukraine}

SUMMARY. The traumatic damage of brain is actual medical and socio-economic problem. Cognitive disorders are important aspects of craniocerebral brain injury in development of complications and disabilities.

The aim of the study was to define the features of cognitive violations at experimental traumatic brain injury (TBI). Experimental TBI was modeling on 65 white rats-males by the V.M. Elskyi \& S.V. Ziablitsev method (2005). The tests «opened field», «mink reflex» and experiment «eight-sleeve labyrinth» were used for cognitive disorders. Oppression of cognitive functions was observed directly after TBI and cognitive functions were renewal during a month. However, indexes of orientative-trying reaction, mink reflex and «eight-sleeve labyrinth» experiment in experimental group did not attain to the levels of control group after the month.

Conclusions. Cognitive dysfunctions were observed in the nearest TBI period and after long date. Absence of complete renewal of cognitive functions testified about necessity target pharmacological facilities.

KEY WORDS: traumatic brain injury; cognitive dysfunction. 